\title{
Morphometrics and ratio of body proportionality of tadpoles of Rhinella icterica (Anura, Bufonidae) at different developmental stages
}

\author{
Lima, MSCS. ${ }^{a *}$ and Pederassi, J. ${ }^{b}$ \\ aFederal University of Piauí - UFPI, Campus Amilcar Ferreira Sobral, Rod. BR 343, Km 3.5, Bairro Meladão, \\ CEP 64800-000, Floriano, PI, Brazil \\ bBioma NGO, Rua Queluz, 125, São Cristóvão, CEP 27264-820, Volta Redonda, RJ, Brazil \\ *e-mail: slmauro@ufpi.edu.br \\ Received August 9, 2011 - Accepted October 10, 2011 - Distributed August 31, 2012
}

(With 3 figures)

\begin{abstract}
The plasticity of the anurans' development is probably related to their great ecological and geographic diversity. Therefore, the understanding of environmental occupation by tadpoles is related to their morphological peculiarities. We evaluated the morphologic development of the larval phases 23, 25, 30, 37, 39 and 42 of Rhinella icterica with the aim of establishing the ratio of growth, the increase in corporal mass in relation to growth and the isometry of the corporal variables for each evaluated stage. We submitted the corporal variables to the Multivariate Allometry and the relation between these variables was evaluated using the Principal Components Analysis. We verified the isometric growth and correlation between the different variables, evaluated the growth according to the body mass and established the proportionality ratio between the corporal regions. Each corporal region evaluated presented a fixed proportionality ratio, regardless of the stage, and the size of this portion was found when its proportionality index was multiplied by the tadpole's total length. This study demonstrates that the larval phase of $R$. icterica presents an isometric growth with proportional development of the corporal parts regardless of the evaluated stage.
\end{abstract}

Keywords: amphibian, allometry, tadpole, ratio of growth.

\section{Biometria e razão de proporcionalidade corpórea em girinos de Rhinella icterica (Anura: Bufonidae) em diferentes estágios de desenvolvimento}

\begin{abstract}
Resumo
A plasticidade do desenvolvimento dos anuros é em razão, provavelmente, da sua grande diversidade ecológica e geográfica, além de que a compreensão da ocupação do ambiente por suas larvas está relacionada às suas peculiaridades morfológicas intra e interespecíficas. Avaliamos aqui o desenvolvimento morfológico das fases larvais 23, 25, 30, 37, 39 e 42 de Rhinella icterica, objetivando estabelecer as suas razões de crescimento, o aumento da massa em relação ao crescimento e a isometria de desenvolvimento corporal para cada estágio avaliado. Para tal, submetemos as variáveis corpóreas à Alometria Multivariada, sendo o relacionamento entre essas variáveis avaliado pela análise dos Componentes Principais. Verificamos a isometria do crescimento e a correlação entre as diversas variáveis, além de avaliarmos o crescimento em função da massa corpórea e estabelecermos a razão de proporcionalidade entre as regiões corpóreas. Cada região corpórea avaliada apresentou uma razão de proporcionalidade fixa, independente do estágio, sendo o tamanho dessa região encontrada quando seu índice de proporcionalidade era multiplicado pelo comprimento total. Este estudo demonstra que a fase larvar de R. icterica apresenta crescimento isométrico com desenvolvimento proporcional das regiões corpóreas independentemente do estágio avaliado.
\end{abstract}

Palavras-chave: anfíbio, alometria, girino, razão de crescimento. 


\section{Introduction}

The study of anurans, especially in the larval stage, involves knowledge that ranges from the understanding of the environment where they develop, mostly as temporary as their phase, to how they can develop in water courses occupying lentic and lotic environments or even the leaf litter.

Using larval characters in taxonomic studies of anurans helps in the phylogenetic knowledge (Cruz, 1990; Duellman and Trueb, 1994; Wild, 1995) making it easier to understand these characters and their morphology in the adult phase (McDiarmid and Altig, 1999). Various authors described tadpoles in their work (Peixoto, 1987; Heyer et al., 1990; Cruz and Dias, 1991; Wogel et al., 2004; Rossa-Feres and Nomura, 2006; Nascimento and Skuk, 2006; Vieira and Arzabe, 2008), however most of these studies focus exclusively on the larval phase between stages 37 and 39 .

In Brazil, only $40 \%$ of the tadpoles were known until 2004 (Andrade et al., 2007). This small proportion of species with described tadpoles sh of increasing tows the need to increase the number of registers and studies related to anurans' semaphoronts.

On an international scale, the outlook is not very different because until 1999 just $30 \%$ of the tadpoles had been described to the anurans species (McDiarmid and Altig, 1999).

According to Fatorelli and Rocha (2008), tadpoles have intraspecific and interspecific morphological peculiarities that constitute important aspects for the understanding of species' occupation to each determined aquatic environment. Therefore, the plasticity of the anurans' development is probably related to their great ecological and geographic diversity (Duellman and Trueb, 1994).

Attempting to understand tadpoles' morphological traits has been studied in-depth: Gosner (1960) studied the development stages; Wilbur and Collins (1973) analysed the ecological aspects associated to tadpoles' metamorphosis; Wassersug and Seibert (1975) investigated the functional studies associated to abiotic aspects; Wassersug and Hoff (1985) studied the hydrodynamics of tadpoles and McDiarmid and Altig (1999) growth rate models in anuran tadpoles' adaptation. These studies defined some tendencies concerning the understanding between the environment and the biological factors that determine the population structure, however they are not sufficient to deplete the studies related to morphology of the various species which present a high plasticity level pressurised by ecological factors.

The knowledge of tadpoles' morphological aspects can serve as a subsidy to the understanding of species conservation or even to add information that helps to understand basic and derivative aspects of these semaphoronts. In the present study, we evaluated the morphological development of six larval stages of Rhinella icterica Spix 1824 with the objective of establishing (1) a probable growth rate, (2) the increase in corporal mass in relation to this growth and (3) the isometry of vector growth of corporal variables between the observed larval stages.

\section{Material and Methods}

\subsection{Classification and development stage}

The didactic chronology regarding the tadpoles' development (anuran's larval stage) begins at stage 1, fertilization of the zygote and finishes in stage 46 with the adult form. Therefore, it is considered a tadpole until stage 45 which presents tail remains. Stages 37 to 39 are those where there is pelvic limb characterization (Gosner, 1960).

\subsection{Morphometrics}

The larvae were measured and weighed in phases 23 , 25, 30, 37, 39 and 42. Each sample corresponded to 50 individuals and the morphometric corresponded to the head length (H.L.), body length (B.L.), tail length, (T.L.), total length (Tt.L.), body height (B.H.), tail height (T.H.) and body mass (M). The measurements were taken using a digital caliper of $0.03 \mathrm{~mm}$ precision and the mass was measured using digital precision scales of one gram. The body parts were based on the proposals by Altig (2007).

\subsection{Evaluation of body growth}

The corporal variables were submitted to Multivariate Allometry where the relation between the head length, the body length, the tail length and the total length were evaluated by the Principal Components Analysis (PCA).

The hypothesis of isometry of vector growth of corporal variables was verified using the test: isometry $=\sqrt{\frac{1}{p}}$. Let $p=$ number of variables, with $(p-1)$ degrees of freedom (DF). Where the vector that is bigger than $\sqrt{\frac{1}{p}}$ indicates positive allometry and smaller, a negative one (Mandarinde-Lacerda, 1995). The correlation between the variables was established by the Spearman Correlation Coefficient $\left(\mathrm{R}^{2}\right)$ and the growth in relation to the corporal mass was evaluated using the Coefficient of Variation of Body Mass (CVBM) using the calculus (Barbosa et al., 2005) (Equation 1):

$\mathrm{CVBM}=100 \mathrm{x} \frac{(\text { Stan } \text { dardDeviation })}{(\text { Mean })}$

The ratio of body proportionality was established through the model $S g=(C T x R p)+1$, where $S g=$ body portion (Gosner, 1960), $C T=$ Total length and $R p=$ Rate of allometric proportion calculated. The differences found between the body values calculated by the ratio of proportionality and the numbers given to each development stage were submitted to the adherence test $C h i$-square $\left(\chi^{2}\right.$, $n-1 D F$ and $p<0,01)$.

Each tadpole's sample was kept in an individual recipient and incorporated into the Eugenio Izecksohn Herpetological Collection, Biology Institute, Federal Rural University of Rio de Janeiro (EI 11.011). 


\section{Results and Discussion}

Three hundred tadpoles were measured, distributed in six development stages $(23,25,30,37,39$ and 42), making a total of 50 individuals for each stage. Stage 39 was the phase that presented the biggest corporal dimensions, and the body length and tail length were the biggest among the evaluated phases, whose morphometrics average corresponded to $10.01 \mathrm{~mm}$ and $13.36 \mathrm{~mm}$ respectively. Stage 23 presented the smallest corporal dimension as its corporal average was $6.15 \mathrm{~mm}$ for the body length and 7.4 $\mathrm{mm}$ for the tail length. When we evaluated all the corporal dimensions for the six R. icterica tadpoles' development stages, it was clear that the development of the four variables presented the isometric growth between stages 23, 25, 30 and 39, while in stages 37 and 42 heteromorphic growth occurred (see Figure 1).

The intraspecific variable is important to understand the nature of the species, as well as the evolution that consists of converting the variable of the species in differences between the specimens (Alford, 1986). Although our studies did not enable us to understand the mechanisms that dictate the phenotypic plasticity of $R$. icterica, this plasticity seems to be fundamental during the larval stages of development once the morphological heterotypic grows in phases 37 and 42, that is, the growth rates of their body parts, which before were sequential and proportional, lose this constant changing abruptly. We believe that in stage 37 this occurred, because it corresponded to the phase where there was a loss of the exclusive condition of tadpoles and it adds the separate fingers of its limbs to its morphology.

This also took place in stage 42 , where the tail was still the only the corporal part of a tadpole. Hence, stages 37 and 42 were two phases which showed strong morphologic transition. The first was the transition from the premetamorphic phase to the pro-metamorphic phase and the second from the pro-metamorphic phase to the metamorphic climax phase.

The isometric evaluation of the morphological characters for $R$. icterica's tadpoles' development stages proceeded according to three allometric approaches: the PCA (Principal Components Analysis); the Spearman Correlation Coefficient $\left(\mathrm{R}^{2}\right)$ and the diagram of individual scores. Thus, stage 23 showed isometric growth between the tail length and the body in relation to the total length, with a positive correlation: $\mathrm{R}^{2}=0.73$ for body length and $\mathrm{R}^{2}=0.83$ for tail length. Stage 25 presented a strong correlation between the total length and the tail length $\left(R^{2}=0.96\right)$ and less with the body length $\left(\mathrm{R}^{2}=0.83\right)$. For stage 30 , the scores were: tail length $\left(R^{2}=0.67\right)$ and body length $\left(R^{2}=0.57\right)$. Stage 37 presented a correlation between the total length and the tail length $\left(\mathrm{R}^{2}=0.69\right)$ and a weak correlation for the body length $\left(\mathrm{R}^{2}=0.37\right)$. Stage 39 presented a correlation between the total length and the tail length $\left(R^{2}=0.67\right)$ and a weak correlation for the body length $\left(R^{2}=0.27\right)$. Stage 42 presented a strong correlation between the total length and the tail length $\left(\mathrm{R}^{2}=0.81\right)$ and a weak correlation for the body length $\left(\mathrm{R}^{2}=0.39\right)$. For all the development stages, the other body parts, the tail and body height were null, not presenting correlation with the total length (see Figure 2).

Altig and McDiarmid (1999) understand that there are two phases with remarkable changes in the tadpole's morphology, before stage 25 and after stage 42 . Regarding stage 42 , there are no doubts, but regarding stage 25 , we can conclude based on our studies that stage 23 presents a larger proportion to the tail than to the body, which does not mean, however, that it presents significant differences in relation to stage 25 . The only difference is that the corporal correlations' tail length and body length are bigger and adjust better to the isometric sigmoid in stage 25 .

The principal component analysis promoted the linear combination establishing the biggest proportion of the intrabody components variability, where all the components present positive allometric growth (as shown in Table 1).

For all measured development stages of R. icterica, its corporal segments presented the same isometric profile, that is, its highest growth rate was a body length with a variation between $31 \%$ and $43 \%$, followed by the tail length with $24 \%$ and $30 \%$, tail height between $15 \%$ and $24 \%$ and the lowest growth rate to body height, varying between $11 \%$ and $15 \%$. It should be mentioned that for all the stages studied, an increasing development occurred, except in stage 37 whose rates were higher than those calculated at stage 39 and it equalized the rates of stage 42 oin tail length (as shown in Table 1 - CP2).

The maximum growth for each stage of development is preceded by an allometric exponential related to embryogenesis and ontogeny, however when it achieves a certain metamorphosis threshold its metamorphic potential is modulated by many ecological factors (Alford, 1999; Rossa-Feres and Nomura, 2006). In the present study, the boundary stage corresponded to phase 30 , because stages 23,25 and 30 maintain the same proportionality development and a strong alteration takes place in stage 37 , in which the larvae loses its exclusive hydrodynamic aspect and adds its new morphology characters related to the fore limbs.

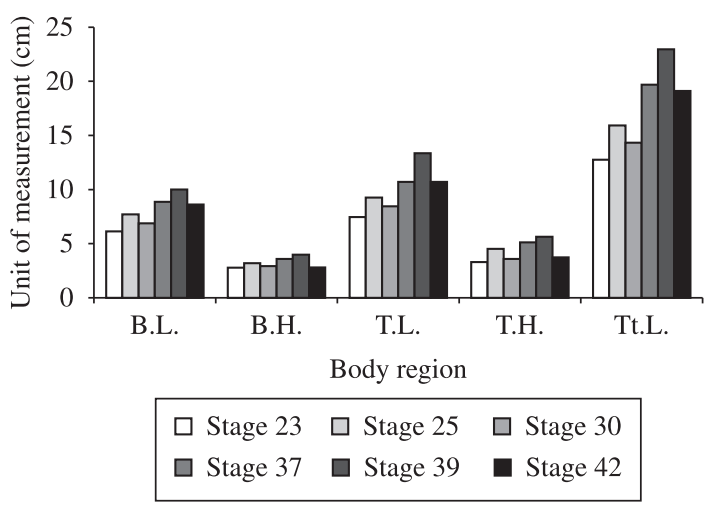

Figure 1. Central Measures Distribution of the corporal characters of R. icterica in the six development stages. Total Length (Tt.L.); Body Length (B.L.); Tail Length (T.L.). 
Table 1. Correlation Matrix of the principal components of the 50 biomeasured individuals of $R$. icterica, stages 23, 25, 30, 37, 39 and 42.

\begin{tabular}{|c|c|c|c|c|}
\hline \multicolumn{5}{|c|}{ Correlation Matrix - Stage 23} \\
\hline & Eigenvalues & Total $\%$ of variancy & Cumulative eigenvalue & Cumulative $\%$ \\
\hline Component 1 & 1.63 & 40.72 & 1.63 & 40.72 \\
\hline Component 2 & 0.96 & 24.07 & 2.59 & 64.79 \\
\hline Component 3 & 0.88 & 22.15 & 3.48 & 86.93 \\
\hline Component 4 & 0.52 & 13.07 & 4.00 & 100.00 \\
\hline \multicolumn{5}{|c|}{ Correlation Matrix - Stage 25} \\
\hline & Eigenvalues & Total $\%$ of variancy & Cumulative eigenvalue & Cumulative $\%$ \\
\hline Component 1 & 1.43 & 35.73 & 1.43 & 35.73 \\
\hline Component 2 & 1.05 & 26.20 & 2.48 & 61.93 \\
\hline Component 3 & 0.93 & 23.36 & 3.41 & 85.29 \\
\hline Component 4 & 0.59 & 14.70 & 4.00 & 100.00 \\
\hline \multicolumn{5}{|c|}{ Correlation Matrix - Stage 30} \\
\hline & Eigenvalues & Total $\%$ of variancy & Cumulative eigenvalue & Cumulative $\%$ \\
\hline Component 1 & 1.26 & 31.59 & 1.26 & 31.59 \\
\hline Component 2 & 1.14 & 28.50 & 2.40 & 60.09 \\
\hline Component 3 & 0.97 & 24.34 & 3.38 & 84.43 \\
\hline Component 4 & 0.62 & 15.57 & 4.00 & 100.00 \\
\hline \multicolumn{5}{|c|}{ Correlation Matrix - Stage 37} \\
\hline & Eigenvalues & Total $\%$ of variance & Cumulative eigenvalue & Cumulative $\%$ \\
\hline Component 1 & 1.41 & 35.30 & 1.41 & 35.30 \\
\hline Component 2 & 1.16 & 29.12 & 2.58 & 64.42 \\
\hline Component 3 & 0.79 & 19.69 & 3.36 & 84.12 \\
\hline Component 4 & 0.63 & 15.88 & 4.00 & 100.00 \\
\hline \multicolumn{5}{|c|}{ Correlation Matrix - Stage 39} \\
\hline & Eigenvalues & Total $\%$ of variance & Cumulative eigenvalue & Cumulative $\%$ \\
\hline Component 1 & 1.75 & 43.75 & 1.75 & 43.75 \\
\hline Component 2 & 0.99 & 24.78 & 2.74 & 68.53 \\
\hline Component 3 & 0.72 & 18.08 & 3.46 & 86.61 \\
\hline Component 4 & 0.53 & 13.39 & 4.00 & 100.00 \\
\hline \multicolumn{5}{|c|}{ Correlation Matrix - Stage 42} \\
\hline & Eigenvalues & Total $\%$ of variance & Cumulative eigenvalue & Cumulative $\%$ \\
\hline Component 1 & 1.69 & 42.40 & 1.69 & 42.40 \\
\hline Component 2 & 1.20 & 30.07 & 2.90 & 72.47 \\
\hline Component 3 & 0.62 & 15.59 & 3.52 & 88.06 \\
\hline Component 4 & 0.48 & 11.94 & 4.00 & 100.00 \\
\hline
\end{tabular}

$\mathrm{CP} 1$ = body length, $\mathrm{CP} 2$ = tail length, $\mathrm{CP} 3$ = tail height and $\mathrm{CP} 4$ = body height.

As demonstrated, the proportional and sequencial isometry loses this constant, abruptly changing the body parts growth rates when the tadpole achieves stage 37, retaking the same condition of proportionality and sequencing in stage 39 and making way for a new alteration in the development proportionality rate in stage 42 . Rossa-Feres and Nomura (2006), concluded that the external morphology is constituted by a set of morphologic characters, some of which retain the evolutive history, while others are more plastic and therefore, susceptible to environmental pressure.
In the present study, it was possible to infer that the body alterations between the pre-metamorphic and prometamorphic phases (stage 30 to stage 37 ) and metamorphic climax (stage 39 to stage 42 ) are not only from a phenotypic nature, otherwise evidence would be shown of the allometric constant for the 300 biomeasured individuals.

The individual body mass of the 300 tadpoles presented a higher coefficient of variation for stage $23(\mathrm{CVBM}=32)$ and a lower one for stage $37(\mathrm{CVBM}=13)$, stages 30 and 39 showed the closest approach to the coefficient for body 

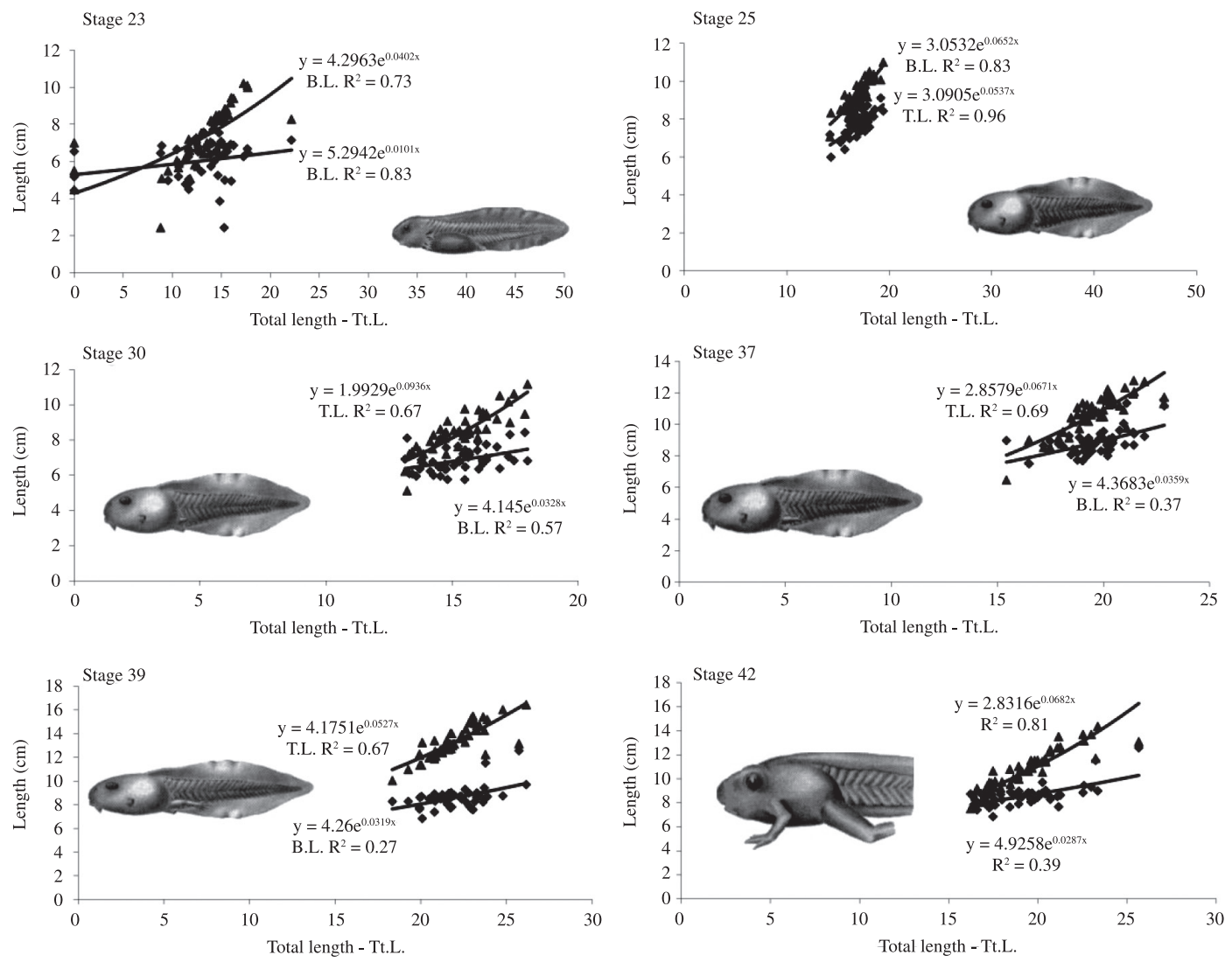

Figure 2. Allometric Correlation (Spearman $\mathrm{R}^{2}$ ) between the total length (Tt.L.) and the body length (B.L.) and the tail length (T.L.) of $R$. icterica in the stages 23, 25, 30, 37, 39 and 42.

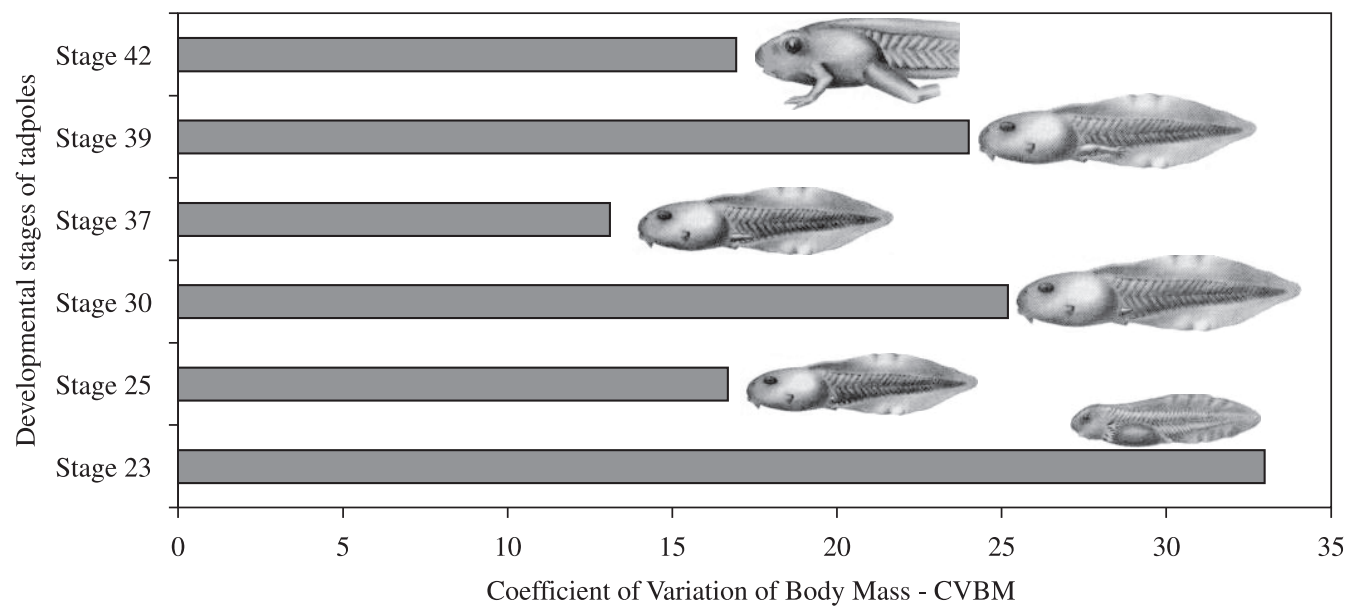

Figure 3. Coefficient of variation of body mass (CVBM) to stages 23, 25, 30, 37, 39 and 42.

mass, and was respectively $(\mathrm{CVBM}=25$ and 24$)$. Stage 42 , the most advanced development phase in the present study, presented a low coefficient of variation of body mass CVBM $=16$ (see Figure 3 ).

When we condense the allometric values observed in the six development stages and 300 tadpoles, it was possible to establish an average increase for each one of the body portions dependent on its respective development stages as shown in Table 2.

The ratio of body proportionality was found for each body part regardless of the development stage of R. icterica's tadpole. Each body region presented a fixed development 
Table 2. Average ( $\dot{\mathrm{x}}$ ) and Standard Deviation (SD), in mm, of corporal segments: total length (Tt.L.), body length (B.L.), Tail length (T.L.), Tail height (T.H.), Body height (B.H) to the six development stages.

\begin{tabular}{|c|c|c|c|c|c|c|}
\hline \multirow[b]{2}{*}{$\begin{array}{l}\text { Corporal } \\
\text { segment }\end{array}$} & \multicolumn{6}{|c|}{ Development stage } \\
\hline & 23 & 25 & 30 & 37 & 39 & $\frac{42}{x}$ \\
\hline Tt.L. $(\dot{\mathrm{x}})$ & 12.76 & 15.93 & 14.34 & 19.68 & 22.97 & 19.11 \\
\hline Tt.L. (SD) & 4.50 & 4.22 & 4.00 & 2.11 & 2.27 & 1.95 \\
\hline B.L. ( $\dot{x})$ & 6.15 & 7.71 & 6.89 & 8.87 & 10.01 & 8.63 \\
\hline B.L. (SD) & 1.08 & 0.58 & 0.67 & 0.83 & 1.12 & 0.89 \\
\hline T.L. ( $\dot{\mathrm{x}})$ & 7.46 & 9.27 & 8.45 & 10.72 & 13.37 & 10.72 \\
\hline T.L. (SD) & 1.57 & 0.75 & 1.12 & 1.20 & 1.32 & 1.67 \\
\hline T.H. $(\dot{\mathrm{x}})$ & 3.30 & 4.52 & 3.59 & 5.12 & 5.64 & 3.74 \\
\hline T.H. (SD) & 0.59 & 0.27 & 0.47 & 0.33 & 0.59 & 0.41 \\
\hline B.H. $(\dot{\mathrm{x}})$ & 2.79 & 3.21 & 2.93 & 3.59 & 3.99 & 2.82 \\
\hline В.H. (SD) & 0.42 & 0.33 & 0.88 & 0.30 & 0.57 & 0.35 \\
\hline
\end{tabular}

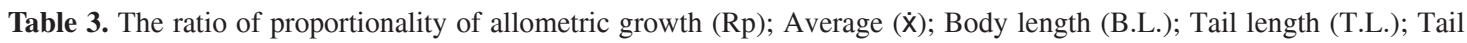
height (T.H.) and Body height (B.H.) to the six development stages.

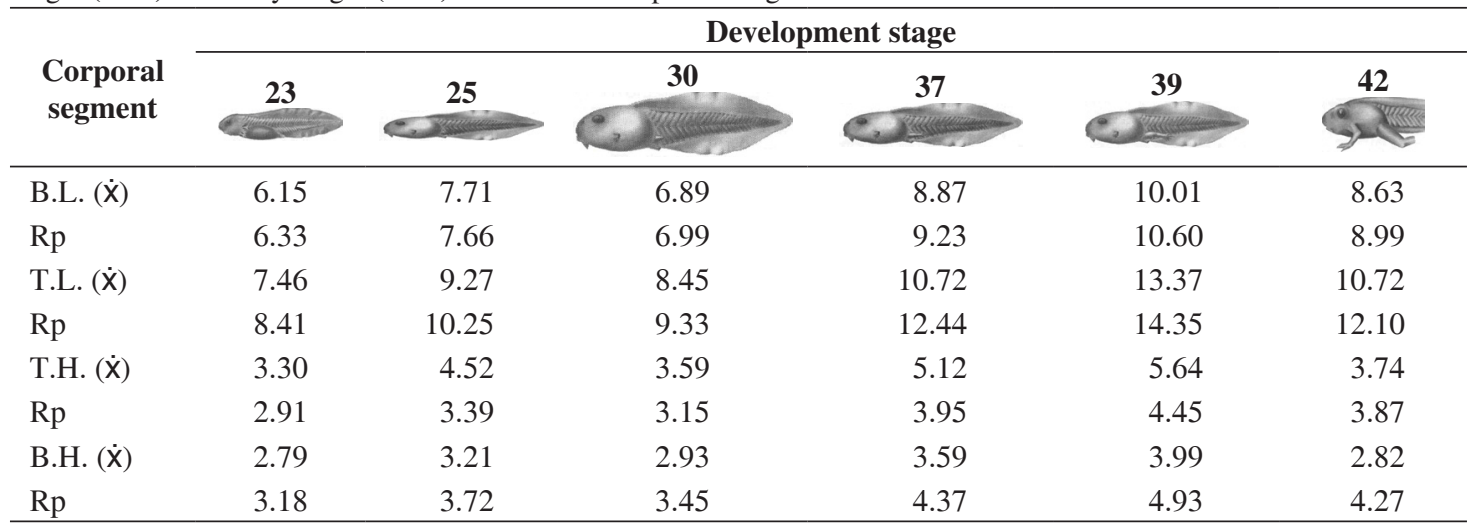

Table 4. Adherence test of the ratio of proportionality of allometric growth. $\chi^{2}$ Chi-square, Body length (B.L.), Tail length (T.L.), Tail height (T.H.) and Body height (B.H.).

\begin{tabular}{ccccc}
\hline & B.L. & T.L. & T.H. & B.H. \\
\hline$\chi^{2}$ & 0.06849 & 0.744518 & 1.161984 & 1.003707 \\
\hline
\end{tabular}

proportion that, when multiplied by the total length, it was calculated. Thus, each corporal part corresponded to the ratio of body proportionality of: B.L. 0.418, T.L. 0.581, B.H. 0.171, T.H. 0.150. When these ratios were applied to the surveyed body parts, we found differences as shown in Table 3.

The differences found between the values given and calculated were submitted to an adherence test of $\chi^{2}$, where the differences were not significant to any of the ratios of proportionality found. (as shown in Table 4).

Based on the data of the present study, considering the development stages, tadpoles' origins and local conditions, it can be concluded that the studied relations presented consistent dependency between the biometric variables of the evaluated tadpoles, whose straight line adjusted to the total length in function of the body length and tail length, fits the model (Potency, $\mathrm{Y}=\mathrm{b} 0 *(\mathrm{~L} * * \mathrm{~b} 1)$ per stage. However, the ratio of proportionality, regardless of the development stage, depends on the total length and corresponds to $41 \%$ of the body length; $58 \%$ to the tail length; $17 \%$ to the body height and $15 \%$ to the tail height.

Rhinella icterica, in its larval phase, demonstrated isometric development and maintained proportional corporal growth during the developmental stages, presenting strong approximation to a potential value of growth. 


\section{References}

ALFORD, RA., 1986. Habitat use and positional behaviour of anuran larvae in a northern Florida temporary pond. Copeia, no. 2, p. 408-423.

-, 1999. Ecology. In McDIARMID, RW. and ALTIG, R. (Eds.). Tadpoles: The biology of anuran larvae. Chicago: The University of Chicago Press. p. 240-278.

ALTIG, R., 2007. A primer for the morphology of anuran tadpoles. Herpetological Conservation and Biology, vol. 2, no. 1, p. 71-74.

ALTIG, R. and McDIARMID, RW., 1999. Body plan: development and morphology. In McDIARMID, RW. and ALTIG, R. (Eds.). Tadpoles: The biology of anuran larvae. Chicago: The University of Chicago Press. p. 24-51.

ANDRADE, GV., ETEROVICK, PC., ROSSA-FERES, DC. and SCHIESARI, L., 2007. Estudos sobre girinos no Brasil: histórico, conhecimento atual e perspectivas. In NASCIMENTO, LB. and OLIVEIRA, E. (Org.). Herpetologia no Brasil II. Belo Horizonte: Sociedade Brasileira de Herpetologia. vol. 1, p. 127-146.

BARBOSA, JM., SILVEIRA, AM. and GOMIDE, CA., 2005. Crescimento heterogêneo de girinos de rã-touro alimentados com diferentes rações. Pesquisa Agropecuária Brasileira, vol. 40, no. 10, p. 1015-1019. http://dx.doi.org/10.1590/S0100204X2005001000010

CRUZ, CAG., 1990. Sobre as relações intergenéricas de Phyllomedusinae da Floresta Atlântica (Amphibia, Anura, Hylidae). Revista Brasileira de Biologia $=$ Brazilian Journal of Biology, vol. 50 no. 3, p. 709-726.

CRUZ, CAG. and DIAS, AG., 1991. Girinos do grupo microcephala do Estado do Rio de janeiro (Amphibia, Anura, Hylidae). Revista Brasileira de Zoologia, vol. 7, no. 4, p. 679-683.

DUELLMAN, WE. and TRUEB, L., 1994. Biology of Amphibians. Baltimore: Johns Hopkins Press.

FATORELLI, P. and ROCHA, CFD., 2008. O que molda a distribuição das guildas de girinos tropicais? Quarenta anos de busca por padrões. Oecologia Brasiliensis, vol. 12, no. 4, p. 733-742.

GOSNER, KL., 1960. A simplified table for staging anuran embryos and larvae with notes on identification. Herpetologica, vol. 16, p. 183-190.
HEYER, WR., RAND, AS., CRUZ, CAG., PEIXOTO, OL. and NELSON, CE., 1990. Frogsof Boracéia. Arquivos de Zoologia, vol. 31, no. 4, p. 231-410.

MANDARIN-DE-LACERDA, CA., 1995. Métodos Quantitativos em Morfologia. EDUERJ.

McDIARMID, RW. and ALTIG, R., 1999. Tadpoles, the Biology of Anuran Larvae. Chicago: The University of Chicago Press.

NASCIMENTO, FAC. and SKUK, GO., 2006. O girino de Chiasmocleis alagoanus Cruz, Caramaschiand Freire, 1999 (Anura: Microhylidae). Biota Neotropica, vol. 6, no. 3. http:// dx.doi.org/10.1590/S1676-06032006000300021

PEIXOTO, OL., 1987. Caracterização do grupo perpusilla e reavaliação da posição taxonômica de Ololygon perpusilla perpusilla e Ololygon perpusilla v-signata (Amphibia, Anura, Hylidae). Arquivos da Universidade Federal Rural do Rio de Janeiro, vol. 10, no. 1-2, p. 37-49.

ROSSA-FERES, DC. and NOMURA, F., 2006. Characterization and taxonomic key for tadpoles (Amphia: Anura) from the northwestern region of São Paulo State, Brazil. Biota Neotropica, vol. 6, no. 1.

VIEIRA, WLS. and ARZABE, C., 2008. Descrição do girino de Physalaemus cicada (Anura, Leiuperidae). Iheringia. Série Zoologia, vol. 98, p. 266-269. http://dx.doi.org/10.1590/S007347212008000200016

WASSERSUG, RJ. and HOFF, K., 1985. The kinematics of swimming in anuran larvae. Journal of Experimental Biology, vol. 119, p. 1-30.

WASSERSUG, RJ. and SEIBERT, E., 1975. Behavioral responses of amphibian larvae to variation in dissolved oxygen. Copeia, no. 1 , p. 86-103.

WILBUR, HM. and COLLINS, JP., 1973. Ecological aspects of amphibian metamorphosis. Science, vol. 182, p. 1305-1314.

WILD, ER., 1995. New genus and species of Amazonian Microhylid frog with a phylogenetic analysis of New World genera. Copeia, no. 4 , p. $837-849$.

WOGEL, H., ABRUNHOSA, PA. and PRADO, GM., 2004. The tadpole of Chiasmocleis carvalhoi and the advertisement calls of three species of Chiasmocleis (Anura, Microhylidae) from the Atlantic rainforest of southeastern Brazil. Phyllomedusa: Journal of Herpetology, vol. 3, no. 2, p. 133-140. 
